Przemysław Krawczyk

Uniwersytet Wrocławski, Izba Adwokacka we Wrocławiu

przemyslawkrawczyk3@gmail.com

ORCID: https://orcid.org/0000-0002-5462-3540

\title{
Individual Responsibility of the Head of State, Head of Government and the Senior Government Officials for international crime. Voice in discussion
}

http://dx.doi.org/10.12775/SIT.2020.010

\section{Research question}

In the following text it will be described understanding of immunities of Head of State, Head of Government and Senior Government Official under the statutory and customary international law sensu largo, in the last paragraph of these article the conclusion will be presented and the main question will be answered, and the question is: Is Head of State, Head of Government and respectively Senior Government Official protected by the immunity in the case of committing an international crime?

\section{Introduction}

The concept of the immunity is almost as old as our civilization itself. Over time, like everything else it evolved, but the essence 
remains unchanged. Nowadays the absolute immunity of Head of State, and Senior Government Officials is contested by Courts, and by international community. The Case of Wilhelm the II had proven that even a monarch ${ }^{1}$, that ruled from the grace of God, would not be impune before the international community for certain crimes. After numerous wars, moral and social revolutions there is no more truth in the words of Louis the XIV L'État c'est moi ("I am the State"). Practice of European Council members shows that, in their opinion responsibility of the Heads of State (also a Senior Government Officials ad maiori ad minus) for an international crime makes an immunity void. Norwegian Government in the statement made to Norwegian Parliament (Storting) following the discussion about the ratification of the International Criminal Court treaty, as fallows: "Evolution of law also tends to make it so that heads of State can no longer benefit from immunity for the most serious crimes". ${ }^{2}$ The Polish Government also made the statement in the same matter, stating that the "responsibility of state officials under international law, regardless of their office and function (including crimes covered by the jurisdiction of the Court) constitutes a clearly binding norm of the customary international law as formed on the basis of the Nuremberg rules and subsequent international practice (the Pinochet case)". ${ }^{3}$ The concept of the state responsibility as well as persons' individual responsibility is still evolving in international law. Nowadays, the trend is directly opposite to what it used to be, i. e. that modern times offer the possibility of bringing a person accused of committing an international crime to court, regardless of whether he or she enjoys immunity or not. This is reflected, for example, in the will and practice of states to give the possibility of assigning responsibility to an individual under international criminal law, which has notabene, become effective with the establishment of the International Criminal Court, as well as its regional

${ }^{1}$ The immunities of monarchs are a separate issue that goes well beyond the framework of this paper.

2 Proposition $\mathrm{n}^{\circ} 24$ (1999-2000) to the Storting.

${ }^{3}$ Progress Report by Poland, 7 August 2001, Consult/ICC 2001 (22), p. 4. 
predecessors, the ad hoc criminal justice system, and the hybrid criminal justice system. ${ }^{4}$

\section{Immunity rationae materiae}

\section{v. personae}

Immunity rationae personae of the incumbent Heads of State and the Heads of Government is well established rule in the international law as they are the States representatives abroad. The question arises with the position of Minister for Foreign Affairs. We should remember that the Vienna Convention on the Law of the Treaties (1969) in Article 7 para 2 (a) and in article 63 and 67 of the Convention. In the drafts to the aforementioned Convention the International Law Commission stated "[...] considered in international law as representing his State without having to produce an instrument of full powers. [...] representatives are entitled to rely on the qualification of the person concerned to represent his State without calling for evidence of it. [...] Heads of State, Heads of Government and Ministers for Foreign Affairs, who are considered as representing their State for the purpose of performing all acts relating to the conclusion of a treaty." 5 Before of aforementioned articles coming in to power it was stipulated in the Ihlen case $e^{6}$ by the Permanent Court of International Justice in the judgement. The PCIJ stated in the Court's view, "it is beyond dispute that the answer given by the Minister of Foreign Affairs [...], in a matter within his competence, is binding on the State which he represents". ${ }^{7}$ As

\footnotetext{
${ }^{4}$ See more in E. Karska, Międzynarodowy Trybunał Karny (International Criminal Court), in: Wspótczesne sądownictwo międzynarodowe. Tom I Zagadnienia instytucjonalne (Contemporary international justice. Volume I Institutional Issues), J. Kolasa (ed.), Wrocław 2009, pp. 163-164 and B. Krzan, Międzynarodowe trybunały karne ad hoc, in: Współczesne (Contemporary...), pp. 191-197.

${ }^{5}$ International Law Commission, Draft Articles on the Law of Treaties with commentaries, "Yearbook of the International Law Commission" 1966, Vol. II.

${ }^{6}$ Legal Status of Eastern Greenland (Norway v. Denmark), PCIJ, 1933 (ser. A/B) No. 53, p. 71.

7 Ibidem.
} 
Arthur Watts rightly stated "foreign ministers bear a personal responsibility in international law for those international acts which are so serious as to constitute international crimes". ${ }^{8}$ Those three persons are the States' representatives on international 'stage'. With that being said we should address the matter of the difference between the rationae personae and rationae materiae aspect of the immunities. The incumbent States' representatives (Head of State, Head of Government and Minister for Foreign Affairs) enjoy the rationae personae immunity, that protects them before the jurisdiction of the another State for the acts that mentioned person had committed while being in office as well in official as in private capacity. ${ }^{9}$ In the Pinochet case Lord Browne - Wilkinson noticed "It is a basic principle of international law that one sovereign state (the forum state) does not adjudicate on the conduct of a foreign state. The foreign state is entitled to procedural immunity from the processes of the forum state. This immunity extends to both criminal and civil liability. State immunity probably grew from the historical immunity of the person of the monarch. In any event, such personal immunity of the head of state persists to the present day: The Head of State is entitled to the same immunity as the state itself. The diplomatic representative of the foreign state in the forum state is also afforded the same immunity in recognition of the dignity of the state which he represents. This immunity enjoyed by a Head of State in power and an ambassador in post is a complete immunity attached to the person of the Head of State or ambassador and rendering him immune for all actions or prosecutions whether or not they relate to matters done for the benefit of the state. Such immunity is said to be granted ratione personae". ${ }^{10}$ The French Court of Cassation in the Gaddafi case stated that „international custom bars the prosecution of incumbent Heads

8 A. Watts, The Legal Position in International Law of Heads of States, Heads of Governments and Foreign Ministers, "Recueil Des Cours" 1994-III, Vol. 247, p. 111.

${ }^{9}$ Immunity is a negative procedural condition during a person's term of office in relation to acts committed in private capacity.

${ }^{10}$ Pinochet case, Regina v. Bartle and the Commissioner of Police for the Metropolis and Others Ex parte Pinochet Ugarte, No. 3, 2000, 1 AC 147, p. 278. 
of State, in the absence of any contrary international provision binding on the parties concerned, before: the criminal courts of a foreign State". ${ }^{11}$ As long the person is in office, he or she enjoys the rationae personae immunity, the ratio of it is that the Senior Government Officials are representing the sovereign State, therefore they should be granted an immunity that allows them act without any obstacles. ${ }^{12}$ Immunity of the High-Ranking States Officials flows directly from the States immunity that is an effect of the States sovereignty. Rationae materiae immunity is somewhat different because it protects the former Senior Government Officials before being tried under the jurisdiction of the foreign countries for the acts that they have committed while being in office but when they act in the official capacity. The acts of the former Senior Government Officials must be in connection with the function that the person in question had perform. The person is immune, however that does not mean that the state cannot be responsible for the acts of that High - Ranking Officials on the grounds that he or she acted on its behalf. ${ }^{13}$ That is the main difference between the personae and materiae immunity, because the latter does not protect the bearer for the private acts of that individual. Law Lords in the Pinochet case concluded that the person that have committed an international crime cannot be protected by diplomatic immunity, because the acts that he committed should not be considered as acts made on behalf of the State, therefore there is no exception to exercise state authority in criminal cases for international criminals even if they are prominent government figures. ${ }^{14}$ As Lord Millett stated "In my opinion there was no immunity to be waived. The offence is one which could only be committed in circumstances which would normally give rise to the immunity. The international community had created an offence for which immunity ratione materiae could

11 Arrêt no. 1414, Cour de cassation, Chambre criminelle, du 13 mars 2001.

12 See W. Czapliński, A. Wyrozumska, Prawo międzynarodowe publiczne (Public International Law), Warsaw 2014, Nb. 269, p. 319.

13 Ibidem, Nb. 270, p. 320.

14 A. Bianchi, Immunity versus Human Rights: The Pinochet Case, "European Journal of International Law” 1999, Vol. 10, No. 2, pp. 237-277. 
not possibly be available. International law cannot be supposed to have established a crime having the character of a jus cogens and at the same time to have provided an immunity which is coextensive with the obligation it seeks to impose". ${ }^{15}$ To sum up, the immunity rationae personae (also known as 'personal immunity') is associated with a person (e. g. monarch), or with the office that he or she holds (e. g. president). A person under this immunity protection may not be brought before a court for acts which were committed in connection with the exercise of his functions or in private capacity. Such a person shall not be liable to the courts of the State if such immunity is granted. The immunity ratione materiae is directly related to the position held by the person concerned; such a person cannot be held liable for acts committed in connection with the exercise of the function which entitles the bearer to that immunity. The condition is that the person concerned must act on behalf of the State and is then free from liability for these acts. Nevertheless, if the acts constitute a tort under international law, the State on whose behalf the person acted may be held liable. ${ }^{16}$

\section{Immunities of Heads of State, Heads of Government and Senior Government Officials under the Vienna Convention on Diplomatic Relations* (1961) and their relations with other relevant sources of international law}

The Article 31 para. 1 aforementioned treaty constitutes grounds for the diplomatic immunity of States' envoys "A diplomatic agent

* The convention entered into force on 24th of April 1964.

${ }_{15}$ Pinochet case, Regina v. Bartle and the Commissioner of Police for the Metropolis and Others Ex parte Pinochet Ugarte, No. 3, 2000, 1 AC 147, p. 93.

${ }^{16}$ The issue of State liability for acts in breach of international law is extensive and therefore far exceeds the framework of this publication. 
shall enjoy immunity from the criminal jurisdiction of the receiving State [...]". We shall at first should answer the question why this convention is applicable to Senior Government Officials, and respectively to the Heads of States. The Vienna Convention on Diplomatic Relations only mentions "diplomatic agent" the phrase has its legal definition in Article 1(e) of this treaty "a "diplomatic agent' is the head of the mission or a member of the diplomatic staff of the mission". Since the Convention itself does not cover its definition, then why it should be applicable to the Heads of State and Senior Government Officials. For the answer we must reach to the Vienna Convention on Law of Treaties (1969) ${ }^{17}$, Article 31 para 1 in connection with Article 32. Decoding the norm hidden in these articles we must also reach to the legal application a fortiori. Ad minori ad maius if the "diplomatic agents" enjoy the immunities, the same immunities have the Senior Government Officials, and respectively Heads of States. It would be contrary to the Vienna's Convention on Diplomatic Relations ratio legis if the immunities did not extend to the aforementioned persons, this would lead to a paradox in which people of lower rank than them would enjoy greater privileges than their superiors. Such reasoning would "lead to an absurd or unreasonable result", in violation of the general principles of interpretation of the Treaties. Our attention also must be drown to the United Nations Convention on Special Missions (1969). ${ }^{18}$ This treaty can be treated as a regulation lex specialis to Vienna Convention on Diplomatic Relations as a lex generali. The immunities in this convention are constructed similar to diplomatic immunities under the Vienna Convention on Diplomatic Relations. In the commentary of International Law Commission to the Draft Articles on Special Missions is stated "The Commission took the

17 The convention entered into force on 27th of January 1980. The convention is an effect of works of International Law Commission, whose main task is to codify international customary law and general principles of international law which are sources of international law accordingly to Article 38 para 1(b) and (c).

${ }_{18}$ The convention entered into force on 21 th of June 1985. As a result of work of ILC it can be considered as a codification of international customary law. 
Vienna Convention on Diplomatic Relations as the basis for the provisions of its draft relating to facilities, privileges and immunities". ${ }^{19}$ In the Article 21 and 29 in connection with Article 31 para 1 of aforementioned Convention had confirmed a special status of the Head of State and persons of high rank, it is clearly stated that they will "enjoy privileges and immunities accorded by international law". The person who is on special state mission in foreign state cannot be arrested and also, they are immune to the criminal jurisdiction of the Courts receiving State. International Court of Justice in the Arrest Warrant of 11 April 2000 case stated "The functions of a Minister for Foreign Affairs are such that, throughout the duration of his or her office, he or she when abroad enjoys full immunity from criminal jurisdiction and inviolability. That immunity and that inviolability protect the individual concerned against any act of authority of another State which would hinder him or her in the performance of his or her duties". ${ }^{20}$ In the same judgement International Court of Justice noticed that "immunity does not mean impunity" ${ }^{11}$ Senior Government Officials can be held responsible for their actions regardless of their immunity if their immunity should be waived by their State, their protection is also void before the courts of their States, they also could bear responsibility for their acts that were committed before and after coming into the office by the individual and also to the activities that have private capacity committed while in office but after but after the person concerned has ceased to perform that function, and what is most important the immunity is not valid before the international courts such as International Criminal Court. ${ }^{22}$

19 International Law Commission, Draft Articles on Special Missions with commentaries, "Yearbook of the International Law Commission" 1967, Vol. II, Part II: Facilities, privileges and immunities, p. 358, para. 5.

${ }^{20}$ Arrest Warrant of 11 April 2000 case (Democratic Republic of the Congo v. Belgium), Judgement, ICJ. Reports 2002, p. 22, para. 54.

21 Ibidem, p. 21, para. 48.

${ }^{22}$ W. Czapliński, A. Wyrozumska, op. cit., Nb. 271-272, pp. 322-323. 


\section{Rome Statute (1998)* vs. immunities of Senior State Officials and Heads of States}

After the horrors of two World Wars international community, "[...] mindful that during this century millions of children, women and men have been victims of unimaginable atrocities that deeply shock the conscience of humanity", have decided that it is needed an impartial body to be above the States that would be able to defend fundamental human rights. This is how the International Criminal Court was created by the will of States. The international criminal law system is not a copy of any national criminal law system, it was created on the basis of legal eclecticism, as was stated "In drafting the statute, the Working Group did not purport to adjust itself to any specific criminal legal system but rather, to amalgamate into a coherent whole the most appropriate elements for the goals envisaged, having regard to existing treaties, earlier proposals for an international court or tribunals and relevant provisions in national criminal justice systems within the different legal traditions". ${ }^{23}$ Therefore, we cannot compare the matter of national regulations on immunities to their equivalent in international criminal law. More to that we shouldn't compare "one to one" with regulations on immunities in public international law. We should rather think of international criminal law, as a self-contained regime ${ }^{24}$ in in-

* The Rome Statute came into force on 1st of July 2002 after the sixty days after sixty State-party ratification of the Statue (Canada's ratification) accordingly to the Article 126 (1) of the Rome Statute.

23 Draft Statute for an International Criminal Court with commentaries, "Yearbook of the International Law Commission” 1994, Vol. II, Part II, p. 26, para. 84.

24 "A self-contained regime covers the case where a set of primary rules relating to a particular subject-matter is connected with a special set of secondary rules that claims priority to the secondary rules provided by general law" M. Koskenniemi, The function and scope of the lex specialis rule and the question of 'self-contained regimes', in: Fragmentation of International Law, 
ternational law. The collision between international criminal and public law should be resolved by usage of the lex speciali derogat legi generali rule. The mentioned rule has a long history in international law as Grotius already pointed out that "What rules ought to be observed in such cases (i.e. where parts of a document are in conflict). Among agreements which are equal that should be given preference which is most specific and approaches most nearly to the subject in hand, for special provisions are ordinarily more effective than those that are general". ${ }^{25}$ The system of International criminal law deals with the crimes of the heaviest gravity, "core crimes". Almost all norms of substantive law of the aforementioned system is jus cogens norms from the international law point of view. This particular self-contained regime protects some of the most and cherished and fundamental values common to all nations against most severe crimes known to mankind. Having that in mind we must differentiate the understanding of the immunities on grounds of international law sensu largo from the meaning of that institutions in a self-contained regime of international criminal law. Under the Article 25 of Rome Statute is hidden a principal of individual responsibility of natural persons, from this norm we can deduce that the Court has jurisdiction over every person, without any exceptions that committed an international crime if the national criminal system is unwilling or unable to exercise its' jurisdiction over that person. The Rome Statute in Article 27 regulates the matter of immunities, it is stated that official capacity of a person is irrelevant in the view of the Court. Every State-Party member of the International Criminal Court, entering and consenting on Article 27 waives the rationae personae immunity of its' officials. ${ }^{26}$

International Law Commission Study Group on Fragmentation, https://legal. un.org/ilc/sessions/55/pdfs/fragmentation_outline.pdf (access: 15.01.2020); look also Case of the SS Wimbledon, PCIJ, Ser. A. No. 1, 1923, p. 23-24.

${ }^{25} \mathrm{H}$. Grotius, De Jure belli ac pacis. Libri Tres, Book II Sect. XXIX.

${ }^{26}$ See C. Lind, Article 27 Irrelevance of official capacity, in: Commentary on the Law of the International Criminal Court, M. Klamberg (ed.), updated 30 April 2017, p. 276, para 279; www.cmn-kh.org/clicc (access: 27.02.2020); and also W.A. Schabas, Article 27, in: The International Criminal Court: A Com- 
Having in mind the previous statement it must be said that the matter of immunities of the member States official is rather clear, they fall under the jurisdiction of International Criminal Court regardless of their official capacity, and the States must render them 'to Hague' if it is necessary. If they are doing opposite, they obstruct an international justice, and they are breaching the general principals of international law - principle of good faith and pacta sunt servanda, and those actions of a State constitute state responsibility under the international law as a lex generali. More problematic matter is responsibility of individuals with an official capacity that are citizens of ICC's non-member States. Before we can answer a question if it is possible for International Criminal Court to have jurisdiction over such persons, we should remind the preconditions to the exercise of jurisdiction of the Court under the Rome Statute:

1) the individual must be accused of committing (at least one) crime that is set forth in article 5 of the Rome Statute;

2) crime must be committed on a State Member territory or the culprit must be under the State-member jurisdiction;

3) the crime must be committed after the 2002 (jurisdiction rationae temporis).

It is sometimes indicated that the International Criminal Court has no jurisdiction over nationals of Non-Member countries. ${ }^{27}$ Inter-

mentary on the Rome Statute, (2nd Edition), W.A. Schabas (ed.), Oxford Public International Law 2016, http://opil.ouplaw.com (access: 12.01.2020).

$27 \mathrm{M}$. Morris notes that there is no practice of States necessary to justify the transfer, as well as subordination, of Non-Party States citizens which would make the recognition of the principle of universal jurisdiction legitimate. This view must be regarded as misguided, since the issue of international criminal liability cannot be considered in the light of classical custom in international law. The norms that are guarded by the ICC have the character of the jus cogens norms, therefore they apply to the international community as a whole. the practice of the States will be produced as a secondary element of the opinio juris vide M. Morris, High Crimes and Misconceptions: The ICC and Non-party States, "Law and Contemporary Problems" 2001, No 64(1), DOI: 64.10.2307/1192354, https://scholarship.law.duke.edu/cgi/viewcontent. cgi?article=1200\&context=lcp (access: 26.02.2020). 
national law is based on the principle of consensus and the required consent of the State to burden it with an international obligation, it does not seem possible for a Court to extend the scope of its jurisdiction beyond that conferred on it by the founding treaty. This would be ultra vires act on its part. We have to remember that in international law the parties of agreement are states not "ordinary individuals", they have their sovereign powers, and their actions are carried out on the basis of sovereignty and equality, as confirmed by Article 2 para 1 of the United Nations Charter. Prima facie the view presented above seems correct. However, if we take a longer time to reflect on this view, it should be firmly rejected. Of course, that's true that States are sovereign and equal inter partes, but we must remember that the states were created to protect individuals. Individuals created them for better protection as a 'social contract', therefore the main goal and purpose of the existence of states is to safeguard individuals ${ }^{28}$ and their rights. The International Criminal Court has a universal jurisdiction over the international criminals regardless of their nationality and whether their State of origin is party to the Statute of ICC if the jurisdictional conditions are fulfilled. ${ }^{29}$ The grounds of the universal jurisdiction in cases where the international criminals were tried were laid down in the Eichmann case in which the Israeli Supreme Court stated that the State prosecuting and punishing the perpetrator of an international crime shall act solely as an authority and representative of the international community which administers justice for violation of the prohibition established by the law of nations. ${ }^{30}$ As demonstrated in the Eichmann case, it is the international community's responsibility to punish those responsible for such serious wrongdoings. Universal

${ }^{28}$ J.J. Rousseau, Oeuvres complètes, B. Gagnebin, M. Raymond (ed.) et al., Vol. III, Paris, 1959-95, p. 361; The Collected Writings of Rousseau, C. Kelley, R. Masters (ed.), Vol. IV, Hanover, 1990, p. 139, and also T. Hobbes, Leviathan, London 1651.

${ }^{29}$ Regardless of above the Court must examine whether it has jurisdiction to hear the case and whether it is admissible on a case-to-case basis.

${ }^{30}$ Eichmann Case, Attorney-General of the Government of Israel v. Eichmann, Israeli Supreme Court, Judgment of 29 May 1962, "International Law Review" 1968, Vol. 36. 
jurisdiction of the Court is also confirmed by the Rome Statute, which states that if a person against whom an arrest warrant has been issued is on the territory of a State - Party it is necessary for that State to make an arrest. That is the state obligation under the international law. If the State fails to comply with this obligation, it will be liable under the general principles of the liability of States for intentionally wrongful acts. The necessity to comply with these obligations, connected with placing the defendant at the disposal of the court, results not only from the statutory law, i. e. the Rome Statute, but also the general principles of international law, which are also reflected in the treaty standards - pacta sunt servanda and good faith. If the arrest warrant granted to the prosecutor and it is issued by ICC it becomes the 'call' for the fulfilment of an obligation of State-Parties accordingly to the International Criminal Court Statute the Bemba case $e^{31}$ is an example of extraterritorial arrest of the defendant. Mr. Bemba was detained in Belgium, after escaping from Democratic Republic of Congo and issued in accordance with the ICC's procedure to Hague. State that have under its jurisdiction the person for which an arrest warrant has been issued cannot contest the Court jurisdiction. The International Criminal Court was created to rule over most serious crimes in entire world, if State-Parties would selectively respect the Court authority whole point of this institution would be destroyed. As a more recent example we can give the Al-Bashir case in which the International Criminal Court rightly pointed out "there is neither State practice nor opinio juris that would support the existence of Head of State immunity under customary international law vis-à-vis an international court. To the contrary, such immunity has never been recognised in international law as a bar to the jurisdiction of an international court". ${ }^{32}$ In the Article 98 of the Rome Statute is stipulated the principle of "cooperation with respect to waiver of immunity and consent to surrender" according to that rule the

${ }^{31}$ Bemba Case, The Prosecutor v. Jean-Pierre Bemba Gombo, 15 June 2009, ICC-01/05-01/08.

32 Al Bashir Case, The Prosecutor v. Omar Hassan Ahmad Al Bashir, Judgment of 6 May 2019, ICC-02/05-01/09-397-Corr., p. 57, para. 113. 
Court cannot "proceed with a request for surrender or assistance which would require the requested State to act inconsistently with its obligations under international law with respect to the State or diplomatic immunity of a person or property of a third State" with the exception that the waiver of the immunity was obtained earlier and also the Court "may not proceed with a request for surrender which would require the requested State to act inconsistently with its obligations under international agreements pursuant to which the consent of a sending State is required to surrender a person of that State to the Court" with the exception when the International Criminal Court had begun cooperation with the sending state earlier. We should driven our attention to the language used in this particular article. The 'third party' should be understood accordingly to the definition of a 'third party' from the Vienna Convention on Law of Treaties (1969), it means that this Party can be a State that is one of the Rome Statue signatories as well as Non - Party State. In the first option there is no possibility of applicability of Article 98 because of the Article 27 of the Statute ${ }^{33}$. In latter as the Pre-Trail Chamber of International Criminal Court has noticed it is not possible to State-Party to deny the jurisdiction of the Court over the person that is under their territorial jurisdiction, even if the person is a citizen of the State that is not party to the Rome Statute, because doing so they would act inconsistently with the whole aim of the Rome Statute. ${ }^{34}$ The state by ratification of the Statute gave the permission to be a part of a jus puniendi of the Court, ${ }^{35}$ with that on her is the burden of international obligation, that she must obliged under the Rome Statute. This position was contested by the Hashemite Kingdom of Jordan, that accordingly to the Vienna Convention on Law of Treaties Article 34 "the Statute

${ }^{33}$ C. Lind, Article 98 Cooperation with respect to waiver of immunity and consent to surrender, in: Commentary on the Law of the International Criminal Court, M. Klamberg (ed.), updated 30 April 2017, p. 665-666, para. 757, www. cmn-kh.org/clicc, (access: 15.01.2019).

${ }^{34}$ Prosecutor v. Omar Al Bashir, ICC PT. Ch., Decision on the Prosecution's Application for a Warrant of Arrest against Omar Hassan Ahmad Al Bashir, ICC-02/05-01/09-3, 4 March 2009, para. 41.

${ }^{35}$ Ibidem, para. 46. 
cannot impose obligations on or deny rights to States that are not parties to the Statute, at least not without their consent" ${ }^{36}$ However, the view of the applicant was not recognised by the Appeals Chamber, which rightly claimed that "Article 98(1) of the Statute does not itself stipulate, recognise or preserve any immunities. It is a procedural rule that determines how the Court is to proceed where any immunity exists such that it could stand in the way of a request for cooperation". ${ }^{37}$

\section{The fair trail right}

Provisions of the Rome Statute are clear, there is no exception for former as well as sitting Heads of States, Heads of Governments and Senior Government Officials, if they are suspects in the case concerning international crime. They should be rendered to the Court in order for them to have a fair trial. Universal Declaration of Human Rights constitutes a basis for aforementioned human right, as is stated in Article 10, that everyone is entitled in full equality to a fair and public hearing by an independent and impartial tribunal, in the determination of his or hers rights and obligations and of any criminal charge against him or her. What should be mentioned the Universal Declaration of Human Rights was not a source of international law since of it creation but in time the Declaration became international customary law, ${ }^{38}$ therefore it

${ }^{36}$ Prosecutor v. Omar Al Bashir, The Hashemite Kingdom of Jordan's appeal against the "Decision under article 87(7) of the Rome Statute on the non-compliance by Jordan with the request by the Court for the arrest and surrender [of] Omar Al-Bashir", No.: ICC-02/05-01/09, 12 March 2019, p. 11, para. 20.

37 Prosecutor v. Omar Al Bashir, Appeals Chamber of ICC Judgment in the Jordan Referral re Al-Bashir Appeal, No. ICC-02/05-01/09 OA2, 6 May 2019, p. 6 , para. 5 .

38 The matter of the creation of custom in international law is a separate issue that goes well beyond the framework of this article. To complete the information, vide W. Czapliński, A. Wyrozumska, op.cit., Nb. 97-116, pp. 97-129, and also W. Góralczyk, S. Sawicki, Prawo międzynarodowe publiczne w zarysie, Warsaw 2004, pp. 96-105. 
became source of international law according to Article 38(1)(b) of International Court of Justice Statute. The elements of international custom appear in the protection by the constitutions of the States of fundamental rights, which are the subject of the regulation of the Declaration. Therefore, the Declaration can be considered as a customary law. Article 10 should be seen in two aspects. On the one hand, it is a guarantee for the entity that the trial concerning he or she will be conducted in accordance with legal standards (active right to a fair trial). On the other hand, it is a guarantee to those affected by the defendant's actions or omissions that they will not be underestimated, and their case will ultimately be brought before the court (passive right to a fair trial). Granting the person who is accused of committing the international crime, crime of such gravity immunity that is absolute would have the effect of denying the individual the protection and exercise of one of his or her fundamental rights, which derive not only from normative acts but also from the very fact of being a human being, from the innate and inalienable dignity of man.

\section{Conclusion}

As it was promised at the beginning, after the analyse of the understanding of immunities in international law sensu largo, we are able came to conclusion and answer the question that was stated in first paragraph - Is Head of State, and respectively Senior Government Official protected by the immunity in the case of committing an international crime? The answer is no. The immunities that the Head of States and High-Ranking Government Officials enjoy are void when it comes to the jurisdiction of International Criminal Court, when They are accused of committing an international crime. It is truth that as well statutory law (The Vienna Convention on Diplomatic Relations and United Nations Convention on Special Missions) as customary international law grants mentioned individuals immunity before national criminal jurisdiction. The key ward in previous sentence is 'national', statutory and customary law cannot protect a person that committed a crime of an international 
rank. If the person in question had breach the jus cogens norm of international criminal law, regardless if these individuals would be protected by immunity rationae materiae or rationae personae, it is possible to try that person for the crimes that he or she committed. As Lord Milles rightly pointed out in the Pinochet case $e^{39}$ we cannot seek an exceptions to these particular jus cogens norms. If we would grant an absolute immunity to a persons, we would made them impune. Nowadays the doctrine of the "divine right to rule" is no longer applicable. Times of Heads of State that rule stricte 'divine gratia' are over. We don't see our leaders as god-like as our ancestors did, we see them as a humans. Therefore, the answer for the question that was asked at the beginning of these article must be negative.

\section{STRESZCZENIE}

Indywidualna odpowiedzialność karna głowy państwa, głowy rządu i wysokich rangą urzędników państwowych za popełnienie zbrodni międzynarodowej.

Głos w dyskusji

Autor niniejszego opracowania poprzez analizę regulacji dotyczących immunitetów głowy państwa, rządu oraz wysokich rangą urzędników państwowych próbuje odpowiedzieć na pytanie, czy owe osoby są chronione przed odpowiedzialnością karną za popełnienie zbrodni międzynarodowej na gruncie międzynarodowego prawa karnego przez immunitet przysługujący im zarówno na gruncie zwyczajowego, jak i stanowionego prawa międzynarodowego. Podczas zgłębiania zagadnienia omawiane są także przykłady z orzecznictwa Międzynarodowego Trybunału Sprawiedliwości oraz Międzynarodowego Trybunału Karnego. Rozważania autora pozwalają mu dojść do wniosku, że nie istnieje nic takiego jak „absolutny immunitet” głowy państwa, rządu oraz wysokich rangą urzędników państwowych

39 Lord Millet in Pinochet case, Regina v. Bartle and the Commissioner of Police for the Metropolis and Others Ex parte Pinochet Ugarte, No. 3, 2000, 1 AC 147, 273, p. 278; https://publications.parliament.uk/pa/ld200506/ /ldjudgmt/jd060614/jones-4.html (access: 27.02.2020). 
w sytuacji popełnienia przez nich zbrodni międzynarodowej. Immunitet przyznany im na gruncie prawa międzynarodowego obowiązuje tylko w odniesieniu do przestępstw „krajowych”, nie ma on jednak zastosowania do zbrodni stypizowanych w Statucie rzymskim.

Słowa kluczowe: immunitet; zbrodnia międzynarodowa; odpowiedzialność jednostki; międzynarodowe prawo karne; absolutny immunitet; odpowiedzialność urzędników; MTS; MTK

\section{SUMMARY}

Individual Responsibility of the Heads of State, Head of Government and the Senior Government Officials for international crime. Voice in discussion

The author of this article, through the analysis of the regulations concerning the immunities of Head of State, Head of Government and Senior Government Officials, tries to answer the question - whether these persons are protected from criminal responsibility for committing an international crime under international criminal law by the immunity they enjoy under both customary and statutory international law. In exploring the issue, examples from the case law of the International Court of Justice and the International Criminal Court are also discussed. The author's deliberations allow him to conclude that there is nothing like the 'absolute immunity' of Head of State, Head of Government and Senior Government Officials in the event of their committing an international crime. Immunity granted to them under international law applies only to "national" crimes, but it does not apply to crimes enshrined in the Rome Statute.

Key words: immunity; international crime; responsibility of an individual; international criminal law; absolute immunity; responsibility of Government Officials; ICJ; ICC

\section{BIBLIOGRAPHY}

Bianchi A., Immunity versus Human Rights: The Pinochet Case, "European Journal of International Law" 1999, Vol. 10, No. 2.

Czapliński W., Wyrozumska A., Prawo międzynarodowe publiczne (Public International Law), Warsaw 2014. 
Góralczyk W., Sawicki S., Prawo międzynarodowe publiczne w zarysie, Warsaw 2004.

Grotius H., De Jure belli ac pacis. Libri Tres, Book II Sect. XXIX.

Hobbes T., Leviathan, London 1651.

International Law Commission, Draft Articles on Special Missions with commentaries, "Yearbook of the International Law Commission" 1967, Vol. II, Part II: Facilities, privileges and immunities.

International Law Commission, Draft Articles on the Law of Treaties with commentaries, "Yearbook of the International Law Commission" 1966, Vol. II.

International Law Commission, Draft Statute for an International Criminal Court with commentaries, "Yearbook of the International Law Commission” 1994, Vol. II, Part II.

Karska E., Międzynarodowy Trybunał Karny (International Criminal Court), in: Wspótczesne sądownictwo międzynarodowe. Tom I Zagadnienia instytucjonalne, J. Kolasa (ed.), Wroclaw 2009.

Koskenniemi M., The function and scope of the lex specialis rule and the question of 'self-contained regimes', in: Fragmentation of International Law, International Law Commission Study Group on Fragmentation, https://legal.un.org/ilc/sessions/55/pdfs/fragmentation_outline.pdf (access: 15.01.2019).

Krzan B., Międzynarodowe trybunały karne ad hoc, in: Wspótczesne sadownictwo międzynarodowe. Tom I. Zagadnienia instytucjonalne (Contemporary international justice. Volume I Institutional Issues), J. Kolasa (ed.), Wrocław 2009.

Lind C., Article 98 Cooperation with respect to waiver of immunity and consent to surrender, in: Commentary on the Law of the International Criminal Court, M. Klamberg (ed.), updated 30 April 2017, www.cmn-kh. org/clicc, (access: 15.01.2019).

Lind C., Article 27 Irrelevance of official capacity, in: Commentary on the Law of the International Criminal Court, M. Klamberg (ed.), updated 30 April 2017, www.cmn-kh.org/clicc, (access: 15.01.2019).

Morris M., High Crimes and Misconceptions: The ICC and Non-party States, "Law and Contemporary Problems" 2001, No 64 (1), DOI: 64. 10.2307/1 192354, https://scholarship.law.duke.edu/cgi/viewcontent. cgi?article=1200\&context=lcp (access: 26.02.2020).

Progress Report by Poland, 7 August 2001, Consult/ICC, 2001 (22).

Proposition No. 24 (1999-2000) to the Storting.

Rousseau J.J., Oeuvres complètes, B. Gagnebin and M. Raymond (ed.) et al., Vol. III, Paris, 1959-95.

Schabas W.A., Article 27, in: The International Criminal Court: A Commentary on the Rome Statute, (2nd Edition), W.A. Schabas (ed.), 2016, Oxford Public International Law, http://opil.ouplaw.com, (access: 12.01.2020). 
The Collected Writings of Rousseau, C. Kelley and R. Masters (ed.), Vol. IV, Hanover, 1990.

Watts A., The Legal Position in International Law of Heads of States, Heads of Governments and Foreign Ministers, "Recueil Des Cours" 1994-III, Vol. 247. 